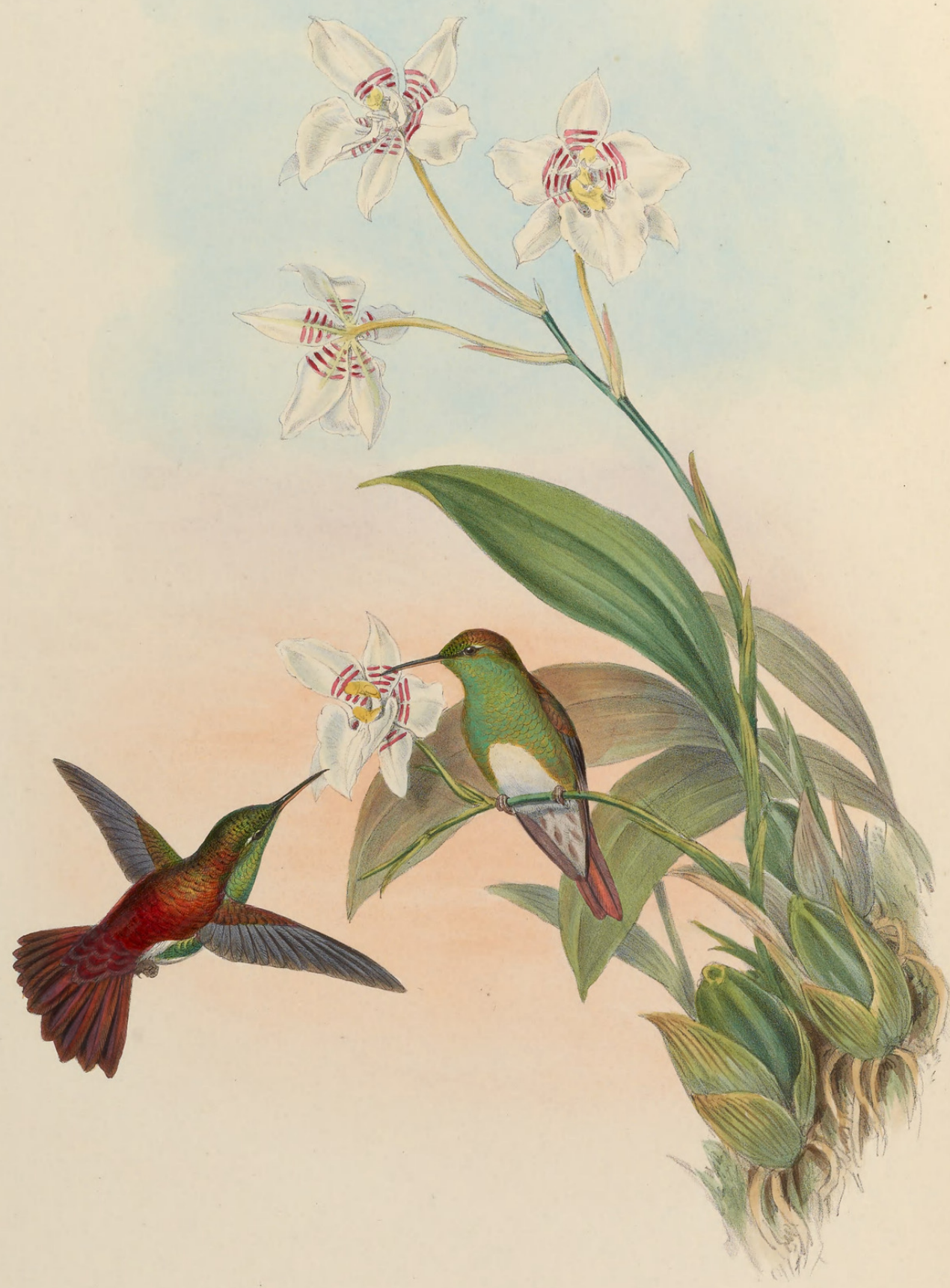




\section{ERYTHRONOTA EDWARDI.}

\section{Wilson's Erythronote.}

Trochilus Edward, De Latt. et Bourc. Rev. Zool. 1846, p. 308.

Polytmus Edwardsii, Gray and Mitch. Gen. of Birds, vol. i. p. 109, Polytmus, sp. 77.

Amazilius Edward, Bonap. Consp. Gen. Av., p. 78, Amazilius, sp. 13.

Thaumantias edward, Bonap. Rev. et Mag. de Zool. 1854, p. 255.

Saucerottia Edwardsii, Reichenb. Aufz. der Col., p. 8.

THE productions of the native country of the Erythronota Edwardi-one of the rarer species of the Trochilidæ-are almost as unknown as those of New Guinea, or any other equally remote part of the globe, which circumstance is very much to be regretted, for were the zoology of the Isthmus of Panama carefully investigated and made known, much of scientific interest would result therefrom.

In size this species equals, if it does not exceed, that of the Common Erythronote; but the whiteness of its belly and the much richer colouring of its back and tail render it remarkably distinct from that and every other species of the genus. I possess several specimens, some of which were procured by the late M. De Lattre, and others by M. Warszewicz.

The Wilson's Erythronote was named Edwardi by MM. De Lattre and Bourcier, in honour of Edward Wilson, Esq., of Tenby, a gentleman who formerly paid great attention to natural history, and particularly to ornithology.

The sexes of this species, like those of the other members of the group, are said to be similar in colour.

Crown of the head and back of the neck green, gradually blending with the deep purplish hue of the shoulders, back and tail-coverts; throat and breast glittering grass-green ; flanks bronzy green ; abdomen white; under tail-coverts brown, bordered with grey; wings purplish brown ; tail rich bronzy purple; bill black, except the basal three-fourths of the under mandible, which are fleshy red.

The figures are of the natural size. The plant is the Odontoglossum membranaceum. 


\section{$2 \mathrm{BHL}$ Biodiversity Heritage Library}

Gould, John. 1861. "Erythronota edwardi, Wilson's Erythronote. [PI. 318]." A monograph of the Trochilidae, or family of humming-birds 5, https://doi.org/10.5962/p.317127.

View This Item Online: https://www.biodiversitylibrary.org/item/108806

DOI: https://doi.org/10.5962/p.317127

Permalink: https://www.biodiversitylibrary.org/partpdf/317127

\section{Holding Institution}

Smithsonian Libraries

\section{Sponsored by}

Smithsonian Institution Libraries

\section{Copyright \& Reuse}

Copyright Status: NOT_IN_COPYRIGHT

This document was created from content at the Biodiversity Heritage Library, the world's largest open access digital library for biodiversity literature and archives. Visit BHL at https://www.biodiversitylibrary.org. 